\title{
Analisis Faktor-Faktor Yang Mempengaruhi Audit Delay: Studi Empiris Pada Perusahaan Pertambangan Batu Bara Yang Terdaftar Di Bursa Efek Indonesia (BEI) Tahun 2010-2015
}

\author{
Novita Eka Paradina \\ Institut Agama Islam (IAI) Yasni Bungo ${ }^{1}$ \\ Email: novitaekaa14@gmail.com
}

\begin{abstract}
This research titled Analysis of factors affecting Audit Delay: Empirical study on Mining Companylisted in Indonesia Stock Exchange Period 2010-2015. The purpose of this research is to examine the impact of firm size, profitability, and solvability and KAP size auditor's opinion toward audit delay in coal mining companies that listed on Indonesia Stock Exchange during 2010-2015.Sampling method that used is purposive sampling and the result are 7 firms as sample. The data used are secondary data, namely the financial statements of companies listed on the Indonesia Stock Exchange in 2010-2015. To prove the hypothesis, performed regression testing the assumptions of panel file test begins Simultaneous testing concluded that all the independent variables(firm size, solvability, auditors opinion, profitability and KAP size) notaffect the dependent variable (audit delay). Partial testing results show that there are two of the five factors that influence to audit delay, KAP size and auditors opinion. Company size profitability and solvability not influence to audit delay.
\end{abstract}

Keyword : Audit delay, firm size, profitability, solvability, KAP size and auditor Opinion

\begin{abstract}
Abstrak
Penelitian ini bertujuan untuk membuktikan secara empiris apakah ukuran perusahaan, profitabilitas, solvabilitas, ukuran kantor akuntan publik, dan opini auditor terhadap audit delay pada perusahaan pertambangan batu bara yang terdaftar di Bursa Efek Indonesia pada tahun 2010-2015.Dalam penelitian ini, penulis mengumpulkan data melalui telaah dokumentasi. Metode pengambilan sampel yang digunakan adalah purposive sampling dan diperoleh sampel sebanyak 6 perusahaan. Data yang dipakai merupakan data sekunder, yaitu laporan keuangan perusahaan yang terdaftar di Bursa Efek Indonesia pada tahun 2010-2015. Guna membuktikan hipotesis, dilakukan pengujian dengan regresi data panel.Pengujian secara simultan menyimpulkan bahwa semua variabel independen mempengaruhi variabel dependen. Pengujian secara parsial memperlihatkan hasil bahwa ada 3 dari 5 faktor yang berpengaruh terhadap auditdelay, yaitu ukuran perusahaan, solvabilitas, dan opini auditor. Profitabilitas dan ukuran KAP tidak berpengaruh terhadap audit delay.
\end{abstract}

Kata Kunci : Ukuran perusahaan, profitabilitas, solvabilitas, ukurankantor akuntan publik dan opini auditor

\section{A. Pendahuluan}

Laporan keuangan haruslah disajikan secara akurat dan tepat waktu pada saat dibutuhkan, karena laporan keuangan memiliki unsur penting dalam hal penyediaan

\footnotetext{
${ }^{1}$ Dosen Fakultas Ekonomi dan Bisnis IAI Yasni Bungo
} 
dan perolehan informasi ${ }^{2}$. Ketepatan waktu perusahaan dalam mempublikasikan laporan keuangan pada masyarakat umum dan kepada BAPEPAM juga tergantung dari ketepatan waktu auditor menyelesaikan laporan auditnya kepada pihak perusahaan yang menjadi kliennya ${ }^{3}$.

Lamanya waktu penyelesaian audit oleh auditor dilihat dari perbedaan waktu tanggal laporan keuangan dengan tanggal opini audit dalam laporan keuangan. Perbedaan waktu ini disebut audit delay. Semakin lama auditor menyelesaikan pekerjaan auditnya, semakin lama pula audit delay. Keterlambatan publikasi laporan keuangan sangat merugikan investor karena dapat meningkatkan asimetris informasi di pasar, insider trading, dan memunculkan rumor yang membuat pasar menjadi tidak pasti. Pada dasarnya banyak faktor yang dapat mempengaruhi audit delay, Berbagai penelitian telah dilakukan, baik didalam negeri maupun diluar negeri ${ }^{4}$.

Telah banyak dilakukan penelitian tentang audit delay, diantaranya, penelitian Trianto, Adri dan Yuneita ${ }^{5}$ Variabel independen yang digunakan adalah ukuran perusahaan, opini auditor, ukuran KAP, solvabilitas dan profitabilitas, sedangkan variabel dependennya adalah audit delay. Penelitian ini menggunakan perusahaan go public yang terdaftar di BEI yang bergerak dalam industri pertambangan pada tahun 2012-2013, Penelitian Sunaningsih dan Rohman ${ }^{6}$ Variabel independen yang digunakan adalah ukuran perusahaan, debt to asset ratio, larning per share, jenis industri, opini auditor dan reputasi KAP, sedangkan variabel dependennya adalah audit delay. Penelitian ini menggunakan seluruh perusahaan jasa yang terdaftar di Bursa Efek Indonesia berturut-turut pada tahun 2011 dan 2012, Penelitian Estrini dan Laksito ${ }^{7}$ Variabel independen yang digunakan adalah profitabilitas, ukuran perusahaan, gender auditor dan reputasi KAP, sedangkan variabel dependennya adalah audit delay.

\footnotetext{
${ }^{2}$ Estrini, et,al . 2013. Analisis Faktor-faktor yang Mempengaruhi Audit Delay (Studi Empiris pada Perusahaan Manufaktur yang Terdaftar di BEI), h. 122

3 Anita, Rohmi. 2011. Pengaruh Tingkat Profitabilitas, Ukuran Perusahaan, dan Ukuran Akuntan Publik Terhadap Audit Delay pada Perusahaan Pertambangan yang Terdaftra di Bursa Efek Indonesia pada Tahun 2008-2009, h.6

4 Trianto, et,al,. 2014. Analisis Faktor-faktor yang Mempengaruhi Audit Delay (Studi Empiris Pada Perusahaan Pertambangan Yang Terdaftar Din Bursa Efek Indonesia). h, 23

${ }^{5}$ Trianto, et,al,. 2014. Analisis Faktor-faktor yang Mempengaruhi Audit Delay (Studi Empiris Pada Perusahaan Pertambangan Yang Terdaftar Din Bursa Efek Indonesia). h, 22

${ }^{6}$ Sunaningsih dan Abdul Rohman. 2014. Faktoe-faktor yang Berpengaruh Terhadap Ausi Delay (Studi Empiris pada Perusahaan Sektor Jasa yang Terdaftar di Bursa Efek IndonesiaPeriode tahun 2011 dan 2012).

${ }^{7}$ Estrini, et,al . 2013. Analisis Faktor-faktor yang Mempengaruhi Audit Delay (Studi Empiris pada Perusahaan Manufaktur yang Terdaftar di BEI), h. 122
} 
Novita Eka Paradina : Analisis Faktor-Faktor...

Penelitian ini menggunakan perusahaan manufaktur yang tercatat di BEI tahun 20092011.

Dalam penelitian ini, peneliti mencoba menggunakan variabel yang telah digunakan oleh penelitian-penelitian sebelumnya, yaitu ukuran perusahaan, profabilitas, solvabilitas, ukuran Kantor Akuntan Publik dan opini auditor. Dikarenakan peneliti tertarik untuk melihat hubungan kelima variabel dengan audit delat, namun menggunakan alat analisis data panel.

\section{Landasan Teori}

Laporan keuangan merupakan pertanggungjawaban pengelolaan perusahaan oleh manajemen atas sumberdaya yang dipercayakan kepadanya. Menurut Chariri dan Ghozali ${ }^{8}$, pengungkapan laporan keuangan berarti bahwa laporan tersebut harus memberikan informasi dan penjelasan yang cukup mengenai hasil aktivitas suatu unit usaha. Dengan demikian, informasi tersebut haruslah lengkap dan jelas serta dapat menggambarkan secara tepat kejadian-kejadian ekonomi yang berpengaruh terhadap hasil operasi usaha tersebut.

Definisi audit yang sangat terkenal adalah definisi yang berasal dari ASOBAC ( $A$ Statement of Basic Auditing Concepts) yang mendefinisikan auditing sebagai suatu proses sistematis untuk menghimpun dan mengevaluasi bukti-bukti secara obyektif mengenai asersi-asersi tentang berbagai tindakan dan kejadian ekonomi untuk menentukan tingkat kesesuaian antara asersi-asersi tersebut dengan kriteria yang telah ditentukan dan menyampaikan hasilnya kepada para pemakai yang berkepentingan ${ }^{9}$.

Tujuan umum audit adalah untuk menyatakan pendapat atas kewajaran dalam semua hal yang material, posisi keuangan sesuai dan hasil usaha serta arus kas sesuai dengan Prinsip Akuntansi Berterima Umum di Indonesia. Sedangkan tujuan auditor menurut SA 700 adalah untuk merumuskan suatu opini atas laporan keuangan berdasarkan suatu evaluasi atas kesimpulan yang ditarik dari bukti audit yang diperoleh dan untuk menyatakan suatu opini secara jelas melalui suatu laporan tertulis yang juga menjelaskan basis opini tersebut.

Audit delay merupakan lamanya atau rentang waktu penyelesaian audit yang diukur dari tanggal penutupan buku sampai dengan tanggal diterbitkanya laporan audit 10 .

\footnotetext{
${ }^{8}$ Chariri dan Imam Ghozali. 2007. Teori Akuntansi. h, 78

${ }_{9}^{9}$ Abdul Halim. 2015. Auditing Dasar-dasar Audit Laporan Keuangan. Ed. Kelima, h 5

${ }^{10}$ Andi Kartika. 2011. Faktor-faktor yang Mempengaruhi audit delay pada Perusahaan Manufaktur yang Terdaftar di BEI. h, 3
} 
Senada dengan pernyataan Aryati ${ }^{11}$ menyebutkan audit delay sebagai rentang waktu penyelesaian laporan audit laporan keuangan tahunan, diukur berdasarkan lamanya hari yang dibutuhkan untuk memperoleh laporan keuangan auditor independen atas audit laporan keuangan perusahaan sejak tanggal tutup buku perusahaan, yaitu per 31 Desember sampai tanggal yang tertera pada laporan auditor independen. Audit delay inilah yang dapat mempengaruhi ketepatan waktu informasi yang dipublikasikan, sehingga akan berpengaruh terhadap tingkat ketidakpastian keputusan yang berdasarkan informasi yang dipublikasikan ${ }^{12}$. Faktor-faktor yang Memperngaruhi Audit Delay, antara lain :

1. Ukuran Perusahaan

Ukuran Perusahaan dapat diartikan sebagai suatu skala di mana dapat diklasifikasikan besar kecil perusahaan dengan berbagai cara antara lain dinyatakan dalam total aktiva, nilai pasar saham, dan lain-lain.

2. Profitabilitas

Profitabilitas menunjukkan keberhasilan perusahaan dalam memperoleh keuntungan. Maka tingkat profitabilitas rendah berpengaruh terhadap audit delay. Hal tersebut berkaitan dengan akibat yang dapat ditimbulkan pasar terhadap pengumuman rugi oleh perusahaan. Owusu-Ansah ${ }^{13}$ mengemukakan bahwa, perusahaan yang memiliki hasil gemilang (good news) akan melaporkan laporan keuangan lebih tepat waktu dibandingkan dengan perusahaan yang mengalami kerugian (bad news). Ungkapan ini sesuai yang dikemukakan dalam penelitian Annisa (2004), perusahaan dengan hasil yang baik akan melaporkan lebih cepat dari perusahaan yang gagal operasi atau merugi.

3. Solvabilitas

Solvabilitas adalah kemampuan perusahaan untuk memenuhi seluruh kewajiban perusahaan yang meliputi utang jangka pendek dan utang jangka panjang, baik perusahaan masih berjalan maupun dalam keadaan dilikuidasi. Suatu perusahaan dikatakan solvabel jika perusahaan mempunyai aktiva atau kekayaan yang cukup

\footnotetext{
11 Titik Aryati dan Maria Theresia. 2005. Faktor-faktor yang Mempengaruhi Audit Delay dan Timeliness:. Media Riset Akuntansi, Auditing dan Informasi. h, 5

12 Andi Kartika. 2011. Faktor-faktor yang Mempengaruhi audit delay pada Perusahaan Manufaktur yang Terdaftar di BEI. $h, 5$

13 Stephen Owosu dan Ansah. 2000. Timeliness of Corporate Financial Reporting in Emerging Capital Market : Empirical Evidence Fram The Zimbabwe Stock Exchange. h, 246
} 
untuk membayar semua utang-utangnya. Sebaliknya jika jumlah aktiva tidak cukup atau lebih kecil dari jumlah utangnya berarti perusahaan tersebut dalam keadaan insolvabel ${ }^{14}$.

4. Ukuran Kantor Akuntan Publik

Penelitian Yuliana dan Ardiati ${ }^{15}$ yang memaparkan Teori De Angelo (1981) menunjukkan bahwa the big five cenderung menyajikan audit yang lebih baik dibandingkan dengan non big five, karena mereka memiliki nama baik yang dipertaruhkan. Selain itu, KAP besar lebih banyak mengeluarkan pendapat going concern daripada KAP kecil.

Usai kasus Enron yang melibatkan KAP Arthur Andersen, the big five menjadi the big four.

5. Opini Auditor

Auditor menyatakan pendapatnya berpijak pada audit yang dilaksanakan berdasarkan standar auditing dan atas temuan-temuannya. Dalam hal pemberian opini, Standar Pelaporan keempat dalam SPAP memaparkan: "Laporan auditor harus memuat suatu pernyataan pendapat mengenai laporan keuangan secara keseluruhan atau suatu asersi bahwa pernyataan demikian tidak dapat diberikan. Jika pendapat secara keseluruhan tidak dapat diberikan, maka alasannya harus dinyatakan. Dalam hal nama auditor dikaitkan dengan laporan keuangan, maka laporan auditor harus memuat petunjuk yang jelas mengenai sifat pekerjaan audit yang dilaksanakan, jika ada, dan tingkat tanggung jawab yang dipikul oleh auditor".

\section{Metode Penelitian}

\section{Jenis Penelitian}

Berdasarkan sifatnya, metode penelitian yang dipergunakan dalam penelitian ini adalah metode kuantitatif.

\section{Objek dan Subjek Penelitian}

Objek penelitian ini adalah variabel-variabel yang akan di uji yaitu variabel independen/bebas dan variabel dependen/terikat. Dalam penelitian ini variabel independen/bebas yang akan diuji kembali adalahukuran perusahaan, profitabilitas, solvabilitas, ukuran kantor akuntan publik dan opini auditor, sedangkan variabel

\footnotetext{
${ }^{14}$ Danang Sunyoto. 2013. Analisis Laporan Keuangan untuk Bisnis. h,61

15 Yuliana dan A.Y. Ardiati. 2004. Faktor-Faktor yang Mempengaruhi Audit Delay

di Indonesia
} 
dependen/terikat adalah audit delay. Pada penelitian ini subjek penelitian nya adalah perusahaan pertambangan batu bara yang terdaftar di Bursa Efek Indonesia (BEI) tahun $2010-2015$.

\section{Metode Pengumpulan Data}

Dalam penelitian ini, penulis mengumpulkan data melalui telaah dokumentasi. Dokumen merupakan catatan peristiwa yang sudah berlalu, bisa berbentuk tulisan, gambar atau karya dari seseorang 16.

\section{Populasi dan Sampel}

Populasi dalam penelitian ini adalah seluruh perusahaan pertambangan sektor batu bara yang terdaftar di Bursa Efek Indonesia (BEI) pada tahun 2010-2015. Populasi perusahaan pertambangan sektor batu bara, antara lain adalah 138 perusahaan pertambangan sektor batu bara. Teknik pengambilan sampel yang digunakan dalam penelitian ini adalah menggunakan teknik purposive sampling. Jumlah sampel 7 perusahaan selama 6 tahun, untuk data yang akan diolah sebanyak 42 data observasi.

\section{Variabel Penelitian dan Definisi Operasional Variabel}

Variabel independen $(\mathrm{X})$ terdiri atas ukuran perusahaan $\left(\mathrm{X}_{1}\right)$, profitabilitas $\left(\mathrm{X}_{2}\right)$, solvabilitas $\left(\mathrm{X}_{3}\right)$, kualitas auditor $\left(\mathrm{X}_{4}\right)$, dan opini auditor $\left(\mathrm{X}_{5}\right)$. Variabel dependennya adalah audit delay(Y).

Tabel 1

Definisi Operasional Variabel Penelitian

\begin{tabular}{|c|l|l|c|}
\hline $\begin{array}{c}\text { Variabel yang } \\
\text { Diukur }\end{array}$ & \multicolumn{1}{|c|}{$\begin{array}{c}\text { Konsep/ } \\
\text { Definisi }\end{array}$} & Skala \\
\hline $\begin{array}{c}\text { Audit Delay } \\
(Y)\end{array}$ & $\begin{array}{l}\text { Audit delay merupakan lamanya } \\
\text { atau rentang waktu penyelesaian } \\
\text { audit yang diukur dari tanggal } \\
\text { penutupan buku sampai dengan } \\
\text { tanggal diterbitkanya laporan } \\
\text { audit 17 }\end{array}$ & $\begin{array}{l}\text { Selisih tanggal } \\
\text { penutupan tahun } \\
\text { buku sampai tanggal } \\
\text { laporan keuangan } \\
\text { auditan. }\end{array}$ & Rasio \\
\hline $\begin{array}{c}\text { Perusahaan } \\
\left(X_{1}\right)\end{array}$ & $\begin{array}{l}\text { Ukuran Perusahaan adalah besar } \\
\text { kecilnya suatu perusahaan yang } \\
\text { di ukur dari besarnya total asset } \\
\text { atau kekayaan yang dimiliki oleh } \\
\text { suatu perusahaan 18 }\end{array}$ & Total asset & Rasio \\
\hline $\begin{array}{c}\text { Profitabilitas } \\
\left(X_{2}\right)\end{array}$ & $\begin{array}{l}\text { Profitabilitas adalah kemampuan } \\
\text { perusahaan dalam menghasilkan }\end{array}$ & Return On Asset (ROA) & Rasio \\
\hline
\end{tabular}

16 Sugiyono. 2009. Metode Penelitian Pendidikan Pendekatan Kuantitatif, Kualitatif dan R\&D.

${ }^{17}$ Andi Kartika. 2011. Faktor-faktor yang Mempengaruhi audit delay pada Perusahaan Manufaktur yang Terdaftar di BEI. h, 3

${ }^{18}$ Trianto, et,al,. 2014. Analisis Faktor-faktor yang Mempengaruhi Audit Delay (Studi Empiris Pada Perusahaan Pertambangan Yang Terdaftar Din Bursa Efek Indonesia). h, 26 
Novita Eka Paradina : Analisis Faktor-Faktor...

\begin{tabular}{|c|l|l|c|}
\hline & laba selama periode tertentu17 & & Rasio \\
\hline $\begin{array}{c}\text { Solvabilitas } \\
\left(X_{3}\right)\end{array}$ & $\begin{array}{l}\text { Solvabilitas adalah kemampuan } \\
\text { suatu perusahaan untuk } \\
\text { memenuhi semua kewajibannya, } \\
\text { baik kewajiban jangka panjang } \\
\text { ataupun jangka pendek 17. }\end{array}$ & $\begin{array}{l}\text { Total debt to total } \\
\text { asset rasio }\end{array}$ & \\
\hline $\begin{array}{c}\text { Ukuran Kantor } \\
\text { Akuntan Publik } \\
\left(X_{4}\right)\end{array}$ & $\begin{array}{l}\text { Kantor Akuntan Publik adalah } \\
\text { lembaga yang memiliki izin dari } \\
\text { Menteri Keuangan sebagai } \\
\text { wadah bagi akuntan publik } \\
\text { dalam menjalankan pekerjaanya } \\
\text { 19 }\end{array}$ & $\begin{array}{l}\text { Terkategori } \\
\text { berafiliasi denganthe } \\
\text { big four/ non big four }\end{array}$ & $\begin{array}{c}\text { Nominal } \\
\text { (Dummy) }\end{array}$ \\
\hline $\begin{array}{c}\text { Opini auditor adalah pendapat } \\
\text { Opini Audit } \\
\left(X_{5}\right)\end{array}$ & $\begin{array}{l}\text { yang diberikan oleh auditor } \\
\text { independen atas laporan } \\
\text { keuangan perusahaan 18 }\end{array}$ & $\begin{array}{l}\text { Pernyataan opini } \\
\text { auditor }\end{array}$ & $\begin{array}{c}\text { (Nominal) } \\
\text { Dummy }\end{array}$ \\
\hline
\end{tabular}

Sumber: Data Diolah Peneliti

\section{Analisis Regresi dengan Data Panel}

Data panel dapat didefinisikan sebagai gabungan antara data silang (cross section) dengan data runtut waktu (time series). Nama lain dari panel adalah pool data, kombinasi data time series dan cross section, micropanel data, longitudinal data, analisis even history dan analisis cohort.Persamaan regresi dengan data panel adalah sebagai berikut:

$$
Y_{i t}=\alpha+\beta_{1} X_{1 i t}+\beta_{2} X_{2 i t}+\beta_{3} X_{3 i t}+\beta_{4} X_{4 i t}+\beta_{5} X_{5 i t}+e_{i t}
$$

Metode data panel dapat dilakukan dengan tiga metode, yaitu metode kuadrat terkecil (pooled least square), metode efek tetap (fixed effect), dan metode efek random (random effect).

\section{Uji Signifikansi Parsial (Uji Statistik t)}

Uji statistik $\mathrm{t}$ pada dasarnya menunjukkan seberapa jauh pengaruh suatu variabel independen secara individual dalam menerangkan variasi variabel dependen ${ }^{20}$. Kriteria pengambilan keputusan adalah sebagai berikut:

a. Apabila $t$ hitung $>t$ tabel dan tingkat signifikansi $(\alpha)<0,05$ maka Ho yang menyatakan bahwa tidak terdapat pengaruh variabel independen secara parsial terhadap variabel dependen ditolak. Ini berarti secara parsial variabel independen berpengaruh signifikan terhadap variabel dependen.

\footnotetext{
${ }^{19}$ Trianto, et,al,. 2014. Analisis Faktor-faktor yang Mempengaruhi Audit Delay (Studi Empiris Pada Perusahaan Pertambangan Yang Terdaftar Din Bursa Efek Indonesia). h, 24

20 Imam Ghozali. 2011. Aplikasi Analisis Multivariate dengan Program SPSS 19.00. h,61
} 
b. Apabila t hitung $<\mathrm{t}$ tabel dan tingkat signifikansi $(\alpha)>0,05$, maka Ho diterima, yang berarti secara parsial variabel independen tidak berpengaruh signifikan terhadap variabel dependen.

\section{Uji Signifikansi Simultan (uji statisti F)}

Uji signifikansi simultan (uji statistik F) bertujuan untuk mengukur apakah semua variabel independen yang dimasukkan dalam model mempunyai pengaruh secara bersama-sama terhadap variabel dependen. Cara pengujian simultan terhadap variabel independen yang digunakan dalam penelitian ini adalah sebagai berikut:

a. Merumuskan hipotesis

$H_{0}: \beta_{1}=\beta_{2}=\beta_{3}=0$, artinya tidak terdapat pengaruh dari variabel independen $\left(X_{1}, X_{2}\right.$ dan $X_{3}$ ) terhadap variabel dependen (Y).

b. Dasar pengambilan keputusan

Jika probabilitas $>0,05$, maka $H_{0}$ diterima artinya tidak berpengaruh

Jika probabilitas $<0,05$, maka $H_{0}$ ditolak artinya berpengaruh

Jika $F_{\text {Hitung }} \geq F_{\text {tabel }}$, maka $H_{0}$ ditolak artinya berpengaruh

Jika $F_{\text {Hitung }} \leq F_{\text {tabel }}$, maka $H_{0}$ diterima artinya tidak berpengaruh

\section{Uji Koefisien Determinasi $\left(R^{2}\right)$}

Koefisien determinasi $\left(\mathrm{R}^{2}\right)$ pada intinya mengukur seberapa jauh kemampuan model dalam menerangkan variasi variabel dependen. Nilai $\mathrm{R}^{2}$ yang kecil berarti kemampuan variabel-variabel independen dalam menjelaskan variasi variabel dependen amat terbatas.Nilai dari $\mathrm{R}^{2}$ berkisar dari 0 - 1 atau 0\% - 100\%. Semakin mendekati nilai 1 atau 100\% maka semakin besar pengaruh variabel independen terhadap variabel dependen.

\section{Hasil dan Pembahasan}

\section{Uji Hausman (Fixed Effect vs Random Effect)}

Uji ini dikembangkan oleh Hausman untuk memilih apakah lebih baik menggunakan Model Fixed Effect atau Random Effect. Statistik Hausman lebih besar dari nilai kritisnya, maka model yang tepat adalah model Fixed Effect, dan sebaliknya (Widarjono, 2009). Berikut ini Uji Hausman yang ditampilkan dalam tabel output: 
Novita Eka Paradina : Analisis Faktor-Faktor...

Tabel 2

Hasil Uji Hausman

Correlated Random Effects - Hausman Test

Pool: OVIT

Test cross-section random effects

\begin{tabular}{lrrr}
\hline \hline Test Summary & $\begin{array}{r}\text { Chi-Sq. } \\
\text { Statistic }\end{array}$ & Chi-Sq. d.f. & Prob. \\
\hline \hline Cross-section random & 0.518729 & 4 & 0.9717 \\
\hline \hline
\end{tabular}

Cross-section random effects test comparisons:

\begin{tabular}{crrrr} 
Variable & Fixed & Random & Var(Diff.) & Prob. \\
\hline \hline X1? & -1.152896 & 0.008599 & 46.321568 & 0.8645 \\
X2? & 0.072014 & 0.071290 & 0.012161 & 0.9948 \\
X3? & 0.011347 & 0.018677 & 0.000222 & 0.6231 \\
X5? & -1.301083 & -1.667858 & 1.295097 & 0.7472 \\
\hline \hline
\end{tabular}

Sumber : data yang diolah

Hipotesis dari uji Hausman adalah:

$\mathrm{H}_{0}:$ Random Effect

$\mathrm{H}_{1}$ : Fixed Effect

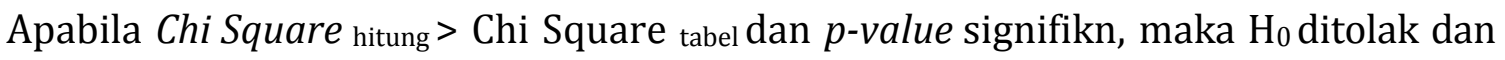
model Fixed Effect lebih tepat digunakan.Berdasarkan output uji Hausman dari eviews terlihat nilai $p$-value $=0.9717>5 \%$ sehingga $\mathrm{H}_{0}$ diterima. Dengan demikian dapat disimpulkan bahwa model Random Effect lebih baik dibandinggkanFixed Effect.

\section{Hasil Estimasi dengan Model Random Effect}

Hasil estimasi model Random Effect dapat dilihat pada tabel output berikut :

\section{Tabel 3}

\section{Hasil Estimasi Random Effect/Pooled EGLS(Cross-Section Random Effect)}

Dependent Variable: Y?

Method: Pooled EGLS (Cross-section random effects)

Date: $11 / 29 / 16$ Time: $18: 30$

Sample: 20102015

Included observations: 6

Cross-sections included: 7

Total pool (balanced) observations: 42

Swamy and Arora estimator of component variances

\begin{tabular}{ccccc}
\hline \hline Variable & Coefficient & Std. Error & t-Statistic & Prob. \\
\hline \hline C & 68.85336 & 167.5757 & 0.410879 & 0.6836 \\
X1? & 0.008599 & 5.734388 & 0.001500 & 0.9988
\end{tabular}


Novita Eka Paradina : Analisis Faktor-Faktor...

\begin{tabular}{|c|c|c|c|c|}
\hline & & & & \\
\hline $\mathrm{X} 2 ?$ & 0.071290 & 0.216886 & 0.328696 & 0.7443 \\
\hline $\mathrm{X} 3 ?$ & 0.018677 & 0.038669 & 0.482991 & 0.6320 \\
\hline $\mathrm{X} 4 ?$ & -2.063989 & 25.49865 & -0.080945 & 0.9359 \\
\hline $\mathrm{X} 5 ?$ & -1.667858 & 4.712395 & -0.353930 & 0.7255 \\
\hline Random Effects (Cross) & & & & \\
\hline _ADRO--C & -0.501104 & & & \\
\hline _BYAN--C & 16.53855 & & & \\
\hline _DEWA--C & $1.78 \mathrm{E}-14$ & & & \\
\hline _HRUM--C & 15.40124 & & & \\
\hline _ITMG--C & -15.97888 & & & \\
\hline _KKGI--C & -8.313300 & & & \\
\hline _PTRO--C & -7.146505 & & & \\
\hline & Effects Sp & cification & & \\
\hline & & & S.D. & Rho \\
\hline Cross-section random & & & 22.20887 & 0.7703 \\
\hline Idiosyncratic random & & & 12.12723 & 0.2297 \\
\hline & Weighted & Statistics & & \\
\hline R-squared & 0.014847 & Mean depend & nt var & 15.03405 \\
\hline Adjusted R-squared & -0.121980 & S.D. depender & var & 10.95478 \\
\hline S.E. of regression & 11.60369 & Sum squared & esid & 4847.246 \\
\hline F-statistic & 0.108509 & Durbin-Watsc & int & 1.178114 \\
\hline Prob(F-statistic) & 0.989738 & & & \\
\hline & Unweighte & Statistics & & \\
\hline R-squared & 0.057229 & Mean depen & tit vat & 69.09524 \\
\hline Sum squared resid & 10430.46 & Durbin-Watsc & int & 0.547494 \\
\hline
\end{tabular}

Sumber : data yang diolah

Hasil regresi menunjukkan bahwa slope variabel X1(Ukuran perusahaan) sebesar 0.001500, slope X2 (Profitabilitas) sebesar 0.328696, slope X3 (Solvabilitas) sebesar 0.482991, slope X4 (Ukuran KAP) sebesar -0.080945 dan slope X5 (Opini auditor) sebesar -0.353930. Sementara nilai p-value X1 (Ukuran perusahaan) adalah 0.9988, X2 (Profitabilitas) sebesar 0.7443, X3 (Solvabilitas) sebesar 0.6320, X4 (Ukuran KAP) sebesar 0.9359 dan X5 (Opini auditor) sebesar0.7255 yang menunjukkan koefisien , X4 (Ukuran KAP) dan X5 (Opini auditor) berpengaruh signifikan secara parsial terhadap audit delay sedangkan X1 (Ukuran perusahaan), X2 (Profitabilitas) dan X3 (Solvabilitas) tidak berpengaruh secara parsial terhadap audit delay.

Nilai probabilita uji F adalah sebesar 0.250886yang berarti X1 (Ukuran perusahaan), X2 (Profitabilitas), X3 (Solvabilitas), X4 (Ukuran KAP) dan X5 (Opini auditor) berpengaruh signifikan secara simultan terhadap audit delay. 
Novita Eka Paradina : Analisis Faktor-Faktor...

Berdasarkan uji Hausman, terlihat bahwa model mengikuti Random Effect. Maka dari hasil estimasi dengan menggunakan model Random Effectdapat dibentuk persamaan sebagai berikut:

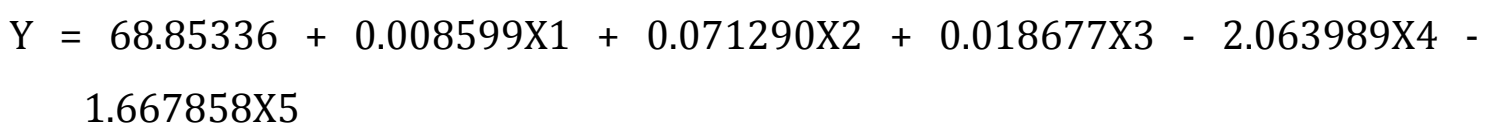

\section{Uji Hipotesis}

\section{Uji t Atau Uji Parsial}

Pengujian ini dilakukan untuk mengetahui signifikansi pengaruh variabel bebas secara individual terhadap variabel terikat.Rumusan hipotesis untuk Uji t adalah sebagai berikut:

$\mathrm{H}_{0}$ : Variabel independen secara parsial tidak berpengaruh terhadap variabel dependen

$\mathrm{H}_{1}$ : Variabel independen secara parsial berpengaruh terhadap variabel dependen.

Uji ini melihat probabilitas signifikansi atas model regresi yang diteliti, jika :

Probabilitas signifikansi $\leq 5 \%$ maka Ho ditolak dan menerima $\mathrm{H}_{1}$

Probabilitas signifikansi $\geq 5 \%$ maka Ho diterima dan menolak $\mathrm{H}_{1}$

\section{Tabel 4}

\section{Hasil Uji t}

\begin{tabular}{crrrr} 
Variable & Coefficient & Std. Error & t-Statistic & Prob. \\
\hline \hline C & 68.85336 & 167.5757 & 0.410879 & 0.6836 \\
X1? & 0.008599 & 5.734388 & 0.001500 & 0.9988 \\
X2? & 0.071290 & 0.216886 & 0.328696 & 0.7443 \\
X3? & 0.018677 & 0.038669 & 0.482991 & 0.6320 \\
X4? & -2.063989 & 25.49865 & -0.080945 & 0.9359 \\
X5? & -1.667858 & 4.712395 & -0.353930 & 0.7255 \\
\hline
\end{tabular}

Sumber: Data diolah

Hasil uji signifikansi parsial untuk Variabel independen Audit Delay Terhadap variabel dependen ukuran perusahaan, profitabilitas, solvabilitas, ukran KAP dan opini auditor adalah sebagai berikut:

a. Variabel ukuran perusahaan tidak mempunyai pengaruh yang signifikan terhadap Audit Delay karena memiliki tingkat signifikansi lebih besar dari 0,05 yaitu 0.9988 (0.9988>0,05). Nilai thitung berdasarkan tabel di atas sebesar 0.001500, sedangkan nilai tabel adalah 2,3033 ( $\mathrm{df}=\mathrm{n}-6, \alpha=5 \%$ ). Nilai $\mathrm{t}_{\text {hitung }}$ lebih kecil dari nilai tabel $(0.001500<2,3033)$. Ini berarti $\mathrm{H}_{0}$ diterima, sedangkan $\mathrm{H}_{1}$ ditolak. Dengan 
Novita Eka Paradina : Analisis Faktor-Faktor...

demikian, ukuran perusahaan (X1) tidak berpengaruh signifkan terhadap Audit delay. (H ditolak).

b. Variabel profitabilitas tidak mempunyai pengaruh yang signifikan terhadap Audit Delay karena memiliki tingkat signifikansi lebih besar dari 0,05 yaitu 0.7443 $(0.7443>0,05)$. Nilai thitung berdasarkan tabel di atas sebesar 0.328696 , sedangkan nilai tabel adalah 2,3033 ( $\mathrm{df}=\mathrm{n}-6, \alpha=5 \%$ ). Nilai $\mathrm{t}_{\text {hitung }}$ lebih kecil dari nilai tabel $(0.328696<2,3033)$. Ini berarti $\mathrm{H}_{0}$ diterima, sedangkan $\mathrm{H}_{1}$ ditolak. Dengan demikian, profitabilitas (X2) tidak berpengaruh signifkan terhadap Audit delay. $\mathbf{( H}_{2}$ ditolak).

c. Variabel solvabiltas tidak mempunyai pengaruh yang signifikan terhadap Audit Delay karena memiliki tingkat signifikansi lebih besar dari 0,05 yaitu 0.6320 $(0.6320>0,05)$. Nilai thitung berdasarkan tabel di atas sebesar 0.482991 , sedangkan nilai tabel adalah 2,3033 ( $\mathrm{df}=\mathrm{n}-6, \alpha=5 \%$ ). Nilai $\mathrm{t}_{\text {hitung }}$ lebih kecil dari nilai tabel $(0.482991<2,3033)$. Ini berarti $\mathrm{H}_{0}$ diterima, sedangkan $\mathrm{H}_{1}$ ditolak. Dengan demikian, solvabilitas (X3) tidak berpengaruh signifkan terhadap Audit delay. $\mathbf{~}_{3}$ ditolak).

d. Variabel ukuran KAP mempunyai pengaruh yang signifikan terhadap Audit Delay karena memiliki tingkat signifikansi lebih besar dari 0,05 yaitu 0.9359 (0.9359 > 0,05). Nilai thitung berdasarkan tabel di atas sebesar -0.080945 , sedangkan nilai tabel adalah 2,3033 $(\mathrm{df}=\mathrm{n}-6, \alpha=5 \%)$. Nilai $t_{\text {hitung }}$ lebih kecil dari nilai tabel $(-0.080945<$ 2,3033). Ini berarti $\mathrm{H}_{0}$ ditolak, sedangkan $\mathrm{H}_{1}$ diterima. Dengan demikian, ukuran KAP (X4) berpengaruh signifkan terhadap Audit delay. ( $\mathbf{H}_{4}$ diterima).

e. Variabel opini auditor mempunyai pengaruh yang signifikan terhadap Audit Delay karena memiliki tingkat signifikansi lebih besar dari 0,05 yaitu 0.7255 (0.7255 > 0,05). Nilai thitung berdasarkan tabel di atas sebesar -0.353930 , sedangkan nilai tabel adalah 2,3033 ( $\mathrm{df}=\mathrm{n}-6, \alpha=5 \%$ ). Nilai $t_{\text {hitung }}$ lebih kecil dari nilai $\mathrm{t}_{\text {tabel }}-0.353930<$ 2,3033). Ini berarti $\mathrm{H}_{0}$ ditolak, sedangkan $\mathrm{H}_{1}$ diterima. Dengan demikian, opini auditor (X5) berpengaruh signifkan terhadap Audit delay. ( $\mathbf{H}_{5}$ diterima).

\section{Uji F atau Uji Simultan}

Rumusan hipotesis untuk Uji t adalah sebagai berikut:

Ho : Variabel independen secara simultan tidak berpengaruh terhadap variabel dependen

$\mathrm{H}_{1}$ : Variabel independen secara simultan berpengaruh terhadap variabel dependen. 
Novita Eka Paradina : Analisis Faktor-Faktor...

Uji ini melihat probabilitas signifikansi atas model koefisien determinasi, jika :

- F hitung $\leq$ F tabel dan Significant $\rho \geq \alpha \rightarrow$ maka hipotesis nol (H0) diterima

- F hitung $>$ F tabel dan Significant $\rho<\alpha \rightarrow$ maka hipotesis nol (H0) ditolak.

\section{Tabel 5}

Hasil Uji F

Weighted Statistics

\begin{tabular}{lrll}
\hline \hline R-squared & 0.014847 & Mean dependent var & 15.03405 \\
Adjusted R-squared & -0.121980 & S.D. dependent var & 10.95478 \\
S.E. of regression & 11.60369 & Sum squared resid & 4847.246 \\
F-statistic & 0.108509 & Durbin-Watson stat & 1.178114 \\
Prob(F-statistic) & 0.989738 & \\
\hline
\end{tabular}

Sumber : data di olah

Nilai $F_{\text {hitung }}$ sebesar 0.108509 dengan tingkat signifiakn 0.989738 , sedangkan nilai $\mathrm{F}_{\text {tabel }}$ pada tingkat 95\% $(\alpha=5 \%)$ adalah $4,22(\mathrm{df} 1=\mathrm{k}-1$ dan df2 $=\mathrm{n}-\mathrm{k}$,df1 $=6-1$ dan

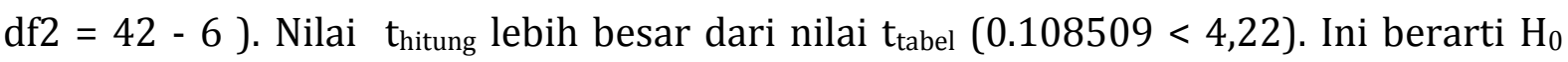
diterima, sedangkan $\mathrm{H}_{1}$ ditolak. Dengan demikian variabel independen ukuran perusahaan, profitabilitas, solvabilitas, ukran KAP dan opini auditor tidak berpengaruh terhadap Audit delay baik secara simultan tidak dapat di terima secara keseluruhan. ( $\mathbf{H}_{\mathbf{6}}$ ditolak).

\section{Koefisien Determinasi $\left(\mathrm{R}^{2}\right)$}

Koefisien determinasi $\left(\mathrm{R}^{2}\right)$ pada intinya mengukur seberapa jauh kemampuan model dalam menerangkan variasi variabel dependen pada penelitian ini dapat di lihat dalam Adjusted $R$ Square, penggunaan Koefisien Determinasi $\left(\mathrm{R}^{2}\right)$ karena menggunakan lebih dari dua variable 21

\section{Tabel 4.16}

\section{Model Summary}

Weighted Statistics

\begin{tabular}{lrll}
\hline \hline R-squared & 0.014847 & Mean dependent var & 15.03405 \\
Adjusted R-squared & -0.121980 & S.D. dependent var & 10.95478 \\
S.E. of regression & 11.60369 & Sum squared resid & 4847.246 \\
F-statistic & 0.108509 & Durbin-Watson stat & 1.178114 \\
Prob(F-statistic) & 0.989738 & \\
\hline \hline
\end{tabular}

Sumber : data diolah

Dari tabel 4.16, nilai adjusted $\mathrm{R}^{2}$ adalah 0,121 . Hal ini berarti 12,1\% variabel Audit delay dapat dielaskan oleh ukuran perusahaan, profitabilitas, solvabilitas, ukran KAP

\footnotetext{
${ }^{21}$ Imam Ghozali. 2011. Aplikasi Analisis Multivariate dengan Program SPSS 19.00. h, 70
} 
dan opini auditor.sisanya sebesar 87,9\% (100\% - 12,1\%) dijelaskan oleh faktor-faktor lain di luar model.

\section{Pembahasan}

\section{Pengaruh Ukuran perusahaan Terhadap Audit Delay}

Berdasarkan hipotesis penelitian H1 bahwa ukuran perusahaan tidak berpengaruh signifikan terhadap audit delay perusahaan. Hal ini dikarenakan adanya peraturan dari BAPEPAM-LK tentang batas waktu pelaporan keuangan yang telah diaudit tanpa membedakan apakah perusahaan tersebut tergolong dalam perusahaan kecil ataupun perusahaan besar ${ }^{22}$. Diperkirakan, ukuran perusahaan tidak berpengaruh terhadap audit delaykarena sampel merupakan perusahaan terdaftar di BEI yang diawasi investor,pengawas permodalan, dan pemerintah. Atas dasar itu, perusahaan dengan asset besarmaupun kecil mempunyai kemungkinan yang sama dalam menghadapi tekanan ataspenyampaian laporan keuangan. Kemungkinan kedua, auditor menganggap bahwadalam proses pengauditan berapapun jumlah aset yang dimiliki tiap-tiap perusahaanakan diperiksa dengan cara yang sama, sesuai dengan prosedur dalam standar profesional akuntan public (Lestari, 2010).

\section{Pengaruh Profitabilitas Terhadap Audit delay}

Berdasarkan hipotesis penelitian $\mathrm{H} 2$ bahwa profitabilitas tidak berpengaruh signifikan terhadap audit delay. Hal ini disebabkan karena kemampuan perusahaan untukmenghasilkan laba berdasarkan aktiva yang dimiliki ternyata tidak mempunyai pengaruh secara signifikan terhadap jangka waktu penyampaian laporan keuangan auditan. Banyak perusahaan yang mengalami kenaikan profit namun kenaikan itu tidak begitu besar, apalagi ada yang mengalami kerugian. Selain itu mungkin tuntutan pihakpihak yang berkepentingan tidak begitu besar sehingga tidak memacu perusahaan untuk mengkomunikasikan laporan keuanganyang diaudit lebih cepat.

\section{Pengaruh Solvabilitas Terhadap Audit delay}

Berdasarkan hipotesis penelitian H3 bahwa solvabilitas tidak berpengaruh signifikan terhadap audit delay perusahaan. Hal ini berarti semakin tinggi tingkat rasio hutang terhadap ekuitas, maka audit delay akan semakin panjang, hal ini dikarenakan rasio hutang terhadap ekuitas menunjukkan kemampuan perusahaan untuk memenuhi segala kewajiban finansialnya pada saat perusahaan dilikuidasi. Semakin tingginya rasio

\footnotetext{
${ }^{22}$ Trianto, et,al,. 2014. Analisis Faktor-faktor yang Mempengaruhi Audit Delay (Studi Empiris Pada Perusahaan Pertambangan Yang Terdaftar Din Bursa Efek Indonesia)
} 
hutang terhadap ekuitas berarti ada permasalahan going concern yang memerlukan audit lebih teliti dan waktu yang lebih lama oleh auditor. Proporsi yang besar dari hutang terhadap total aktiva akan meningkatkan kecenderungan kerugian dan dapat meningkatkan kehati-hatian auditor terhadap laporan keuangan yang akan diaudit. Hal ini disebabkan karena tingginya proporsi dari hutang akan meningkatkan pula risiko keuangannya

\section{Pengaruh Ukuran KAP Terhadap Audit delay}

Berdasarkan hipotesis penelitian H4bahwa ukuran Kantor Akuntan Publik (KAP)berpengaruh signifikan terhadap audit delay. Dikarenakanpada umumnya sistem pengendalian internal perusahaan go public sudah baik, khususnya untuk perusahaan pertambangan. Dengan sistem pengendalian internal yang sudah baik, maka resiko audit akan rendah sehingga jumlah sampel yang akan diaudit menjadi lebih sedikit dan hal ini membuat penyelesaian pekerjaan audit akan semakin cepat. Hal ini mengindikasikan bahwa jika pengendalian internal sebuah perusahaan sudah sangat baik, tidak dibutuhkan auditor dari KAP yang besar untuk menyelesaikan pekerjaan audit dengan lebih cepat.

\section{Pengaruh Opini Auditor Terhadap Audit delay}

Berdasarkan hipotesis penelitian H4,bahwa opini auditor berpengaruh signifikan terhadap audit delayPerusahaan. Hal ini berarti perusahaan yang menerima qualified opinion menunjukkan audit delay yang lebih panjang dibanding yang menerima unqualified opinion. Auditor akan memberikan opini tidak wajar jika laporan keuangan klien tidak disusun berdasarkan prinsip akuntansi yang berlaku umum di Indonesia sehingga tidak menyajikan secara wajar posisi keuangan hasil usaha, perubahan ekuitas dan arus kas perusahaan klien. Auditor tidak akan memberikan opini tidak wajar, apabila ruang lingkup auditnya tidak dibatasi, sehingga dengan demikian auditor dapat mengumpulkan bukti kompeten yang cukup untuk mendukung pendapatnya.

Pengaruh Ukuran perusahaan, Profitabilitas, Solvabilitas, Ukuran Kantor Akuntan Publik (KAP) dan Opini Auditor terhadap Audit Delay Perusahaan

Sebagaimana hipotesis penelitian pada uji overall yang diungkapkan sebelumnya, bahwa ukuran perusahaan, profitabilitas, solvabilitas, ukuran Kantor Akuntan Publik (KAP), dan Opini Auditor tidak berpengaruh signifikan secara bersama-sama terhadap audit delayPerusahaan. Berdasarkan hasil pengujian signifikansi parameter secara 
Novita Eka Paradina : Analisis Faktor-Faktor...

keseluruhan (uji statistik F) pada tabel output seperti yang penulis jelaskan sebelumnya.

\section{E. Kesimpulan}

Hasilpenelitiandan pembahasan mengenai pengaruh variabel ukuran perusahaan, provitabilitas, solvabilitas, ukuran Kantor Akuntan Publik (KAP) dan opini auditorterhadap audit delay perusahaan makadapatditarik kesimpulan sebagai berikut:

1. Tidak terdapat pengaruh yang signifikandari variabelukuran perusahaanterhadapaudit delay perusahaan.

2. Tidak terdapat pengaruh yang signifikan dari variabel profitabilitas terhadapaudit delay perusahaan.

3. Tidak terdapat pengaruh yang signifikan dari variabel solvabilitas terhadapaudit delay perusahaan.

4. Terdapat pengaruh yang signifikan dari variabel ukuran Kantor Akuntan Publik (KAP) terhadapaudit delay perusahaan.

5. Terdapat pengaruh yang signifikan dari variabel opini auditorterhadapaudit delay perusahaan.

6. Tidak terdapatpengaruh yang signifikandari variabel ukuran perusahaan, profitabilitas, solvabilitas, ukuran Kantor Akuntan Publik (KAP), dan Opini Auditorterhadapaudit delay perusahaan yaitu sebesar $12,1 \%$.

\section{F. Saran}

Berdasarkan kesimpulan di atas, maka saran-saran yang dapat diberikan melalui hasil penelitian ini adalah sebagai berikut:

1. Kepada para auditor disarankan untuk melakukan pekerjaan lapangan dengan sebaik-baiknya sehingga pekerjaan dapat dilakukan secara efektif dan efisien dan auditor dapat mengeluarkan laporan hasil audit yang sesuai dengan prosedur dan standar auditing yang ditetapkan Institut Akuntan Publik Indonesia.

2. Investor sebaiknya mencari tahu mengenai data keuangan perusahaan sebaikbaiknya, guna dalam membuat pertimbangan atau prediksi yang akurat untuk menetapkan keputusan investasi.

3. Untuk penelitian selanjutnya diharapkan dapat meneliti lebih dalam yang tidak hanya terbatas pada variabel yang telah diteliti, melainkan perlu adanya penambahan variabel lainnya serta diharapkan dapat menggunakan cakupan obyek penelitian yang lebih luas. Selain itu, di dalam penelitian selanjutanya. 
Novita Eka Paradina : Analisis Faktor-Faktor...

\section{Daftar Pustaka}

Anita, Rohmi. 2011. Pengaruh Tingkat Profitabilitas, Ukuran Perusahaan, dan Ukuran Akuntan Publik Terhadap Audit Delay pada Perusahaan Pertambangan yang Terdaftra di Bursa Efek Indonesia pada Tahun 2008-2009. Universitas Jambi: Jambi

Aryati, Titik dan Maria Theresia.2005. Faktor-faktor yang Mempengaruhi Audit Delay dan Timeliness:. Media Riset Akuntansi, Auditing dan Informasi. 5(3): 271-287.

Chariri, Anis dan Imam Ghozali. 2007. Teori Akuntansi. Semarang: Badan Penerbit Universitas Diponegoro

Estrini, Dwi Hayu dan Herry Laksito. 2013. Analisis Faktor-faktor yang Mempengaruhi Audit Delay (Studi Empiris pada Perusahaan Manufaktur yang Terdaftar di BEI Tahun 2009-2011). Volume 2 Nomor 2, Tahun 2013, Halaman 1 ISSN (Online): 2337-3806. Universitas Diponegoro: Semarang

Ghozali, Imam. 2011. Aplikasi Analisis Multivariate dengan Program SPSS 19.00. Semarang: BPUNDIP

Halim, Abdul. 2015. Auditing Dasar-dasar Audit Laporan Keuangan. Edisi Kelima Jilid 1.Yogyakarta: UPP STIM YKPN.

Kartika, Andi. 2011. Faktor-faktor yang Mempengaruhi audit delay pada Perusahaan Manufaktur yang Terdaftar di BEI. 152 Dinamikan Keuangan

dan Perbankan, Nopember 2011, Hal: 152-171. Vol. 3, No.2. ISSN: 1976-4878: Semarang

Owusu, Stephen \& Ansah. 2000. "Timeliness of Corporate Financial Reporting in Emerging Capital Market : Empirical Evidence Fram The Zimbabwe Stock Exchange". Journal Accounting and Business. Vol. 30. Pp. 241.

Sugiyono. 2009. Metode Penelitian Pendidikan Pendekatan Kuantitatif, Kualitatif dan $R \& D$. Bandung : Alfabeta

Sunaningsih, Suci Nasehati dan Abdul Rohman. 2014. Faktoe-faktor yang Berpengaruh Terhadap Ausi Delay (Studi Empiris pada Perusahaan Sektor Jasa yang Terdaftar di Bursa Efek IndonesiaPeriode tahun 2011 dan 2012). Volume 3, Nomor 2, Halaman 1-11 ISSN. UNDIP. Semarang

Sunyoto, Danang. 2013. Analisis Laporan Keuangan untuk Bisnis. Yogyakarta: CAPS.

Trianto, Imam. R Adri Satriawan dan Yuneita Anisma. 2014. Analisis Faktor-faktor yang Mempengaruhi Audit Delay (Studi Empiris Pada Perusahaan Pertambangan Yang Terdaftar Din Bursa Efek Indonesia). Jom FEKON Vol. 1 No. 2 Oktober 2014. Faculty Economics of Riau University: Pekanbaru

Yuliana dan A.Y. Ardiati. 2004. Faktor-Faktor yang Mempengaruhi Audit Delay di Indonesia. Modus16 (2): 135-146. 